\title{
Chapter 1 \\ Rising Inequalities and a Changing Social \\ Geography of Cities. An Introduction to the Global Segregation Book
}

\author{
Maarten van Ham, Tiit Tammaru, Rulla Ubarevičienė, and Heleen Janssen
}

\begin{abstract}
The book "Urban Socio-Economic Segregation and Income Inequality: a Global Perspective" investigates the link between income inequality and residential segregation between socio-economic groups in 24 large cities and their urban regions in Africa, Asia, Australia, Europe, North America, and South America. Author teams with in-depth local knowledge provide an extensive analysis of each case study city. Based on their findings, the main results of the book can be summarised as follows. Rising inequalities lead to rising levels of socio-economic segregation almost everywhere in the world. Levels of inequality and segregation are higher in cities in lower income countries, but the growth in inequality and segregation is faster in cities in high-income countries, which leads to a convergence of global trends. In many cities the workforce is professionalising, with an increasing share of the top socio-economic groups. In most cities the high-income workers are moving to the centre or to attractive coastal areas, and low-income workers are moving to the edges of the urban region. In some cities, mainly in lower income countries, high-income workers are also concentrating in out-of-centre enclaves or gated communities. The urban geography of inequality changes faster and is more pronounced than citywide single-number segregation indices reveal. Taken together, these findings have resulted in the formulation of a Global Segregation Thesis.
\end{abstract}

\footnotetext{
M. van Ham $(\varangle) \cdot$ T. Tammaru $\cdot$ R. Ubarevičienè $\cdot$ H. Janssen

Delft University of Technology, Faculty of Architecture and the Built Environment, Department of Urbanism, P.O. Box 5043, 2600 GA Delft, The Netherlands

e-mail: m.vanham@tudelft.nl

H. Janssen

e-mail: h.j.janssen@tudelft.nl

T. Tammaru

University of Tartu, Department of Geography, Vanemuise 46, 5104 Tartu, Estonia

e-mail: tiit.tammaru@ut.ee

R. Ubarevičienè

Lithuanian Centre for Social Sciences, Institute of Sociology, Department of Regional and Urban Studies, Vilnius, Lithuania

e-mail: r.ubareviciene@tudelft.nl
}

M. van Ham

School of Geography and Sustainable Development, University of St Andrews, St Andrews, UK

(C) The Author(s) 2021

M. van Ham et al. (eds.), Urban Socio-Economic Segregation and Income Inequality,

The Urban Book Series, https://doi.org/10.1007/978-3-030-64569-4_1 
Keywords Socio-economic segregation • Income inequality $\cdot$ Residential segregation $\cdot$ Global segregation thesis

\subsection{Introduction}

Since the 1980s, globalisation, restructuring of labour markets, and liberalisation of the economy, have led to rising income and wealth inequality across the globe (Piketty 2014; Alvaredo et al. 2018). These rising levels of inequality have consequences for the social and spatial organisation of cities as inequality also has a spatial footprint in the form of socio-economic segregation. When referring to socio-economic segregation we mean an uneven distribution of different occupational or income groups across residential neighbourhoods of a city or an urban region. Research has shown that residential segregation between high-income and low-income groups in European cities has increased in recent decades (Kazepov 2005; Musterd and Ostendorf 1998; Fujita and Maloutas 2016; Tammaru et al. 2016; Musterd et al. 2017; Tammaru et al. 2020). This means that people with high and low incomes are increasingly living separated in different neighbourhoods. Segregation by income is largely driven by the residential choices of higher income households as they have the financial means to realise their housing and neighbourhood preferences (Harvey 1985; Hulchansky 2010; Tammaru et al. 2020). At the same time, lower income households are living in those neighbourhoods where housing is cheap, often in the least desirable parts of a city. Rising levels of segregation cause concern regarding the social sustainability of cities and reduce the status of cities as places of opportunity with equal opportunities for all. As a result, there is increasing attention for understanding intra-urban inequalities and divided cities (see van Ham, Tammaru and Janssen 2018; EU/UN Habitat 2016).

The relationship between income inequality and socio-economic segregation is complex, as it partly depends on the local political, economic, and planning context in cities (see also Tammaru et al. 2016; Musterd et al. 2017). However, there are increasing indications that there is a causal relationship, and that it takes some time before a rise in income inequality leads to higher levels of socio-economic segregation. With other words, there is a time lag between a change in income inequality and a change in levels of segregation (Marcińczak et al. 2015; Musterd et al. 2017; Tammaru et al. 2020; Wessel 2016). This time lag can be explained by the fact that the relationship between income inequality and segregation is a process. As inequality rises, in situ processes will downgrade some neighbourhoods and upgrade others, and over time this will translate into selective residential mobility flows between neighbourhoods, ultimately leading to changes in the level of segregation. However, because of selective mobility, levels of segregation can also drop after a rise in inequality, because high-income groups move into low-income neighbourhoods as is characteristic to gentrification. This drop in levels of segregation at times of growing inequality is referred to as the segregation paradox (Sýkora 2009; Tammaru et al. 2020). As higher 
income groups move into centrally located and attractive lower income neighbourhoods, these neighbourhoods temporarily become more socio-economically mixed and levels of segregation can drop. But as these gentrifying neighbourhoods become unaffordable for lower income households, lower income households move out, and levels of segregation go up. The fact that levels of income inequality have risen globally leads to the expectation that also levels of socio-economic segregation in cities will go up globally.

Another important process in global cities, which is related to segregation, is the changing occupational structure of the workforce. In the 1990s, Sassen (1991) argued that the occupational structure was polarising, with increasing shares of high-income and low-income workers, at the expense of the middle-income group. Hamnett (1994) argued that the concept of social polarisation is ambiguous, and in his work on London he found evidence of processes of professionalisation and socio-economic upgrading (Butler et al. 2008). More recent work has also found evidence of other forms of occupational changes since 2000 (Davidson and Wyly 2015; Manley and Johnston 2014). A very recent paper by van Ham and colleagues (2020) found clear trends of professionalisation in New York, Tokyo, and London, evidenced by a rising share of high-income occupations in all three cities. Professionalisation of the workforce can lead to a dramatically changing social geography of cities without changes in the levels of city-wide single-number measures of segregation. Over the last few decades, high-income workers are increasingly revaluing city life, leading to a high demand for inner city living. Van Ham and colleagues (2020) showed that over the 1981-2011 period levels of segregation in London remained relatively stable, but at the same time the social geography of London turned inside out. Where in the 1980s the rich lived on the edges of London and the poor in the centre, by 2011 this pattern was reversed. A similar process can be seen for the city of Toronto (Hulchansky 2010).

Despite a wealth of knowledge on socio-economic segregation and the changing geography of inequality, there is little internationally comparative research, and many regions of the world are still under researched. This book aims to fill this gap and provides a comprehensive picture of socio-economic segregation in a large number of large cities from all continents. Including cities from all over the globe enables us to study segregation in a truly international context, where many previous studies focussed on a much more limited set of case studies, including mainly Western countries with a good data infrastructure. The main question of this book is: Are there global trends in changes in inequality and segregation, or do cities in different parts of the world show very distinctive patterns of socio-economic segregation? Ultimately, the question is whether there is such a thing as a Global Segregation Thesis? 


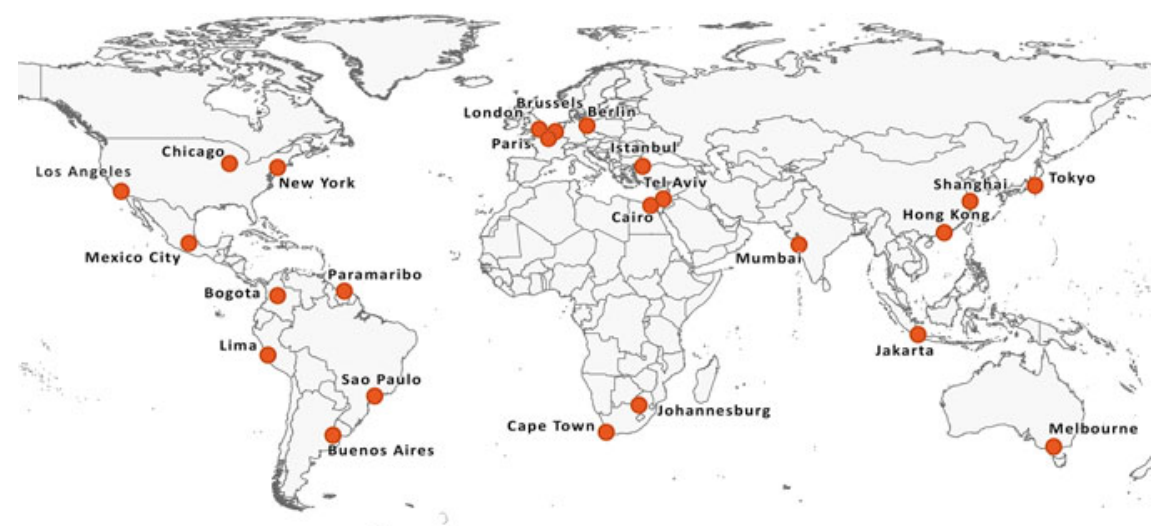

Fig. 1.1 Map of case study cities. Source The authors

The book includes the following case study cities ${ }^{1}$ (see Fig. 1.1): Cairo (Egypt), Cape Town (SAR), Johannesburg (SAR), Hong Kong (Honk Kong), Jakarta (Indonesia), Mumbai (India), Shanghai (China), Tel Aviv (Israel), Tokyo (Japan), Melbourne (Australia), Berlin (Germany), Brussels (Belgium), Istanbul (Turkey), London (UK), Paris (France), Chicago (USA), Los Angeles (USA), Mexico City (Mexico), New York (USA), Bogotá (Colombia), Buenos Aires (Argentina), Lima (Peru), Paramaribo (Suriname), and São Paulo (Brazil). Each of these cities represents global cities in their own context. For some of these cities very detailed data was available for small geographies, while for other cities data was only available for very large spatial units. In addition to chapters on each of these case study cities, the book also includes a chapter which analyses data for 194 cities in 14 OECD countries. This study uses only one year of data but offers the most rigorous comparison of cities possible. The other empirical chapters use data for the 2000/2001-2010/2011 period, and earlier or later data if available and comparable.

Comparing case studies of 24 cities was a challenging task due to the richness of the data and the importance of the local and national context of each city. Based on the case studies we have formulated five main conclusions.

\footnotetext{
${ }^{1}$ We use "city" and "urban region" as synonyms in this introduction.
} 
(1) There is general trend of professionalisation of the occupational structure of cities, with an increase in the share of high-income occupations, and a decrease in the share of low-income occupations. As many high-income workers have a preference for living in central cities, this explains the changing social geography of urban inequality.

(2) Segregation as measured city-wide by the Dissimilarity Index (DI) has increased for most cities (except Cape Town, Johannesburg, Mexico, and Buenos Aires, and excluding some cities with problematic data). Based on our results we expect levels of segregation to increase further in the future, as inequality is increasing, and because in the last decade processes of gentrification have temporarily caused central areas of cities to become more mixed in terms of income.

(3) The higher the level of inequality, the higher the level of segregation. This relationship becomes stronger when lagged inequality data is used. This is because when inequality levels increase, it takes time for this to be reflected in the geography of inequality.

(4) Generally speaking, middle-income countries combine high levels of inequality with high levels of segregation, while high-income countries combine lower levels of inequality with lower levels of segregation. Over time we see that there is convergence between the higher and lower income countries; levels of inequality and segregation in the higher income countries are going up and the gap between the higher and lower income countries is decreasing.

(5) The geography of social inequality is changing faster than levels of segregation measured by the Dissimilarity Index. In most cities the rich are moving to the centre and attractive coastal regions, and the poor are being pushed to the edges of the urban region. Where this does not happen, or sometimes in combination with this trend, the rich also concentrate in enclaves and gated communities.

The remainder of this introduction is organised as follows. First, we present the overall approach of the book; this section deals with the measures, geographies, and definitions used, and it discusses some of the challenges of doing international comparative work. Second, we present how income inequality leads to residential segregation. Next, we discuss the main findings of the book in detail, including summary tables and figures. Finally, this introductory chapter presents a discussion and overall conclusions, with an outlook to the future. After the introduction, each case study city is presented in a separate chapter, authored by expert local teams. The only deviation is Chap. 2, which compares data for one year for a large number of cities in selected OECD countries. 


\subsection{Approach and Justification}

This book provides a systematic comparison of changes in income inequality, occupational change, and socio-economic segregation in large cities around the world over the last decades. As previous studies focussed on either a small number of case studies, or only on European cities, this study will provide a global coverage of cities from all continents, and it includes 24 case study cities in Africa, Asia, Australia, Europe, North America, and South America. Although we aimed for the largest cities, and an even geographical coverage in each of the continents, the final set of case studies was influenced by the availability of research teams and data.

A large-scale internationally comparative project raises many challenges. Not surprisingly, these challenges mostly concern data availability and comparability of case study cities. In the selection of case study cities, we complemented comparability with an inclusive approach, which means that some chapters are not strictly comparable to others. To maximise comparability of cases, the analysis of cities is based on fairly basic and harmonised guidelines (see Appendix 1). The authors were asked to use Functional Urban Areas as defined by the OECD (2013) or equivalent; to create socio-economic groups by categorising occupations into Top, Middle, and Bottom occupational status groups; to provide a city-level Gini index; and they were asked to use the Dissimilarity Index to measure residential segregation between occupations. To analyse the geography of segregation we asked authors to construct a series of maps based on the smallest possible spatial units of analysis (preferably census tracts of around 5000 inhabitants), and data from around 2000 and 2010. Although for some cities more recent data is available (and also presented in their chapters), for most cities 2011 is the year of the most recent census, and hence also the most recent data point.

For only a few case study cities it was possible to closely follow the guidelines. Most of the chapters had to deviate from the guidelines to a certain extent (see Appendix 2 for a detailed overview of the data used per chapter). For example, most chapters use data on occupational categories, but in cases where such data was not available, data was used on education, income, or unemployment. The spatial units of analysis ranged from as small as 800 inhabitants in Buenos Aires to as large as 750,000 inhabitants in Jakarta. The size of urban areas analysed also varies greatly: from 0.4 million inhabitants in Paramaribo to 35.7 million in Tokyo.

The analyses for the cities Berlin, Bogotá, Jakarta, and Mumbai deviate the most from the guidelines because of the lack of comparable data. For that reason, they are not included in our comparative analysis in this introductory chapter. These cities are still included in the book since they do provide very valuable insights on socioeconomic segregation on their own. Jakarta and Mumbai could not be included due to the very large spatial units available for the analysis. Berlin could not be included because of a different indicator available to measure the level of segregation. Bogotá could not be included because only data for 2005 is available that does not allow to study changes in socio-economic segregation. 
Central to this book is the link between income inequality and socio-economic segregation. Ideally, the relationship between inequality (measured using the Gini index) and segregation (measured using the Dissimilarity Index) would be measured at the city-level. However, the Gini index is not available on the city-level for most cities and, as a result, most chapters report inequality data at the country-level. For consistency, country-level Gini data as provided by the World Bank is used in this Introductory chapter. As a consequence, the relationship between inequality and segregation is somewhat weaker compared to using city-level Gini Index. As shown in previous studies, income inequality is almost always higher in large cities as compared to the rest of the country.

All chapters (except Berlin) have used the Dissimilarity Index (DI) to measure city-wide segregation. Although the Dissimilarity Index has certain disadvantages over other measures, it is important to use a simple measure to increase the comparability of cases. See Appendix 1 for more detail on the DI used. The index can range from 0 to 100, and levels of segregation are often categorised as being low when under 30, moderate when between 30 and 60, and high when above 60 (Massey and Denton 1993). This categorisation was initially developed to characterise ethnic and racial segregation in the US. However, this book focusses on socio-economic segregation in an international context, and there are large differences between countries, regions, and cities in the world with regard to what is considered a low or a high level of segregation. While 50 would be very high in Europe (e.g., chapter on Brussels), in Latin America (e.g., chapters on Paramaribo and Buenos Aires) it is considered moderate. Therefore, we find that a strict classification in high and low is not very useful in the context of this book.

Finally, in analysing the results from all the case study cities, it is useful to categorise cities. For this purpose, we have relied on a country classification by income as provided by the World Bank (2020). According to this classification, countries are divided into four income groups: low, lower middle, upper middle, and high. Income is measured using gross national income (GNI) per capita. In 2020, low-income countries are defined as those with a GNI per capita of $\$ 1,025$ or less in 2018; lower middle-income countries are those with a GNI per capita between $\$ 1,026$ and $\$ 3,995$; upper middle-income countries are those with a GNI per capita between $\$ 3,996$ and $\$ 12,375$; high-income countries are those with a GNI per capita of $\$ 12,376$ or more. The countries included in this book fall into the last three categories (see Appendix 2). No low-income country was included in this book due to a lack of data and researchers available to contribute. However, for simplicity, in this introduction we often refer to high-income countries and middle-income countries (pooling together upper middle and lower middle-income countries). 


\subsection{Income Inequality and Segregation}

The level of residential segregation in a city is related to many factors, such as the spatial distribution of housing types by tenure and price. But one of the most important factors is the level of income inequality in society. According to Alverado and colleagues (2018), levels of income inequality dropped globally until the 1980s, and from that point onwards, levels of inequality started to increase again. As a consequence, levels of income inequality are now the highest of the last 30-40 years in most countries in the world. The increase in income inequality is largely related to the increasingly unequal distribution of capital that has accompanied the mass privatisation of public assets since the 1980s, directly affecting the functioning of both labour and housing markets (Alvaredo et al. 2018). This unequal distribution of resources is passed from one generation to another (Corak 2013). Housing is an important element in producing and reproducing inequality, linking thus income inequality and residential segregation to each other (Tammaru et al. 2020). Van Ham et al. (2018) proposed the idea of a vicious circle of inequality and segregation to show how inequality is transmitted from one generation to the next, through a complex interplay of family, housing, education, and labour market factors.

There are different ways to measure inequality, for example, by focussing on the distribution of income or wealth (Alverado et al. 2018). The most widely used and readily available measure of income inequality is the Gini Index, ranging from 0 (perfect equality) to 100 (perfect inequality). Of course, these extremes are never reached in a society, but there is large variation between countries in Gini. The formerly centrally planned countries in the East of Europe had very low values of the Gini Index, and private housing property did not exist. In such a social context, the individual motivation to be creative and to aspire to be economically productive are low, thus restricting economic growth (Kornai 1992). Extremely high levels of inequality are also thought to be harmful as they reduce intergenerational social mobility (Krueger 2012), partly through the operation of the vicious circle of inequality and segregation (van Ham et al. 2018). The negative effects of high levels of income inequality could be seen in South Africa under Apartheid, or in many countries in South America, and include political instability, high rates of poverty and crime, and residential segregation with gated communities for the rich.

Using country-level Gini Index values as harmonised by the World Bank (2020), we find South Africa to be the most unequal country among our case study countries, with Gini Index values exceeding 60 (see Fig. 1.2). In most middle-income countries among our case studies (often located in the Global South), Gini Index values exceed 40. In most high-income countries, Gini Index values are in the range of 30-40, reflecting more extensive income redistribution. Levels of income inequality are the lowest in Europe, with Belgium being the most equal country in our pool of countries with a Gini Index value of 27 . However, there are important exceptions, for example, the level of income inequality is relatively high in the US, with a Gini Index value of more than 40, while the opposite is true for India and Egypt, with Gini Index values below 40 . Not only the levels, but also change in inequality differs by 


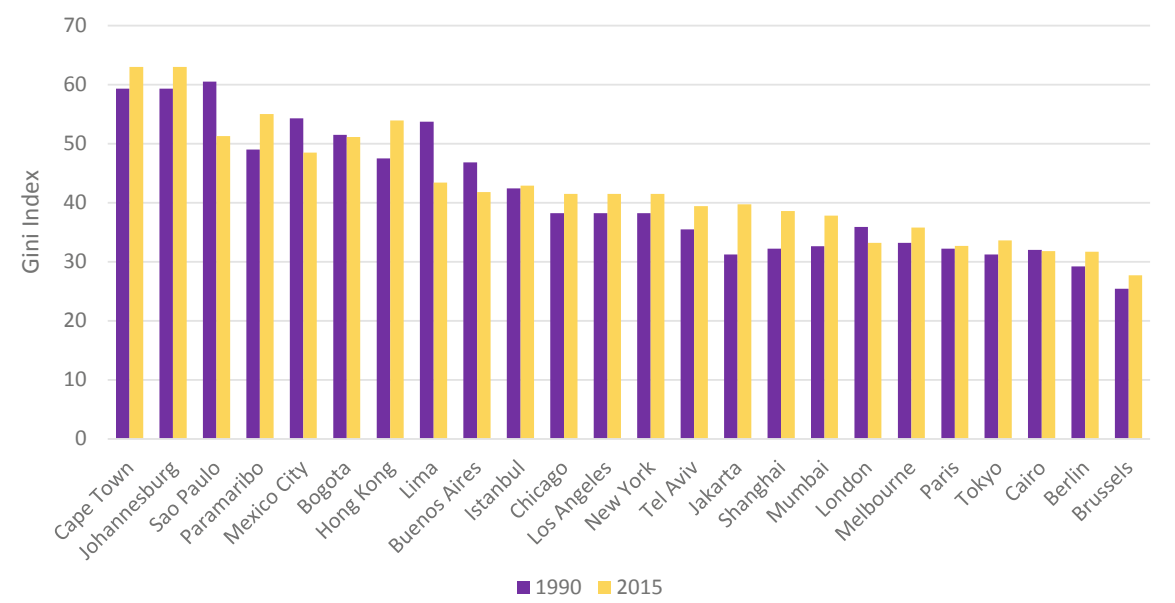

Fig. 1.2 Income inequality, 1990 and 2015. Source World bank. Note When the World Bank data for 1990 and 2015 was not available, we took the closest available years. Instead of 1990 we used data from 1989 for Paris, Mexico City, and Melbourne; 1991 for Berlin, Buenos Aires, Chicago, New York, Los Angeles, and London; 1992 for Bogotá and Tel Aviv; 1993 for Cape Town and Johannesburg; 1997 for Lima; average value between 1988 and 1992 was calculated for Brussels, average value between 1987 and 1993 was calculated for Mumbai and average value between 1987 and 1994 was calculated for Istanbul. When World Bank data was not available at all or incomparable for two data points, we used author-based data, this applies to Hong Kong and Paramaribo

country. While global income inequality started to rise in the 1990s, there are some exceptions such as South America where Gini Index values have decreased since then. In several countries, the level of inequality increased only a little or remained almost stable between 1990 and 2015 (most of Europe). The most systematic increase in income inequality is in Asia, with Hong Kong experiencing the most rapid growth of inequality together with South Africa.

\subsection{Main Results in Five Conclusions}

Based on the detailed study of 24 cities across the world, we have formulated five main conclusions on socio-economic segregation. Together these five conclusions led us to formulate a Global Segregation Thesis, which we discuss further at the end of this chapter. We will now provide a detailed overview of each of the conclusions and present supporting data from the case studies.

\section{Conclusion 1. The occupational structure of most cities is professionalising.}

The first conclusion is that the occupational structure of many cities is professionalising. This is an important conclusion, as it has been suggested that the changing occupational structure is strongly related to the changing social geography of cities (see 
van Ham et al. 2020). The book “The Global City” by Sasia Sassen (1991) provoked a decades-long debate on whether the occupational structure of global cities is polarising or professionalising (see also Hamnett 1994; van Ham et al. 2020). Although there are some exceptions, generally speaking we observe an increase in the share of the Top socio-economic groups, and a decrease (or stabilisation) in the share of the Bottom socio-economic groups. This implies a general trend of professionalisation of the occupational structures also in most of our case studies. The professionalisation of the occupational structure leads to increasing shares of high-income workers, and many of these high-income workers have developed a preference for living in central cities (cf. Hamnett 2009).

Although there are some similar trends, the case study cities vary greatly in their occupational structure and are almost perfectly split into two groups coinciding with the country classification by income (see Appendix 3). In high-income countries, the Top socio-economic groups make up a significantly higher proportion of occupations, compared to the middle-income countries. While the Top socio-economic groups account for about $40 \%$ in Brussels, New York, and Melbourne, they do not exceed $15 \%$ in Jakarta, São Paulo, and Lima. Accordingly, the Bottom socio-economic groups account for at least $40 \%$ in Shanghai, Cairo, São Paulo, and Jakarta, and these groups form less than $15 \%$ in Los Angeles, Melbourne, and Paris. The highest share of the middle socio-economic groups is found in Paramaribo, Paris, and Tel Aviv (around 60\%), while the lowest in Shanghai (14\%). It has to be noted that the definitions of the three groups differ between case study cities, so care should be taken when comparing results. The definition of the Top socio-economic groups is more consistent than the definition of the two other groups. All cities experienced an increase in the share of Top occupations, except for Johannesburg, where the share remained stable, and Brussels, where it dropped slightly, but remained to be one of the highest among the case studies.

\section{Conclusion 2. Segregation measured by the Dissimilarity Index has increased for most cities.}

Analysing data from the 20 comparable case studies ${ }^{2}$ reveals a large variety in segregation levels between the Top and Bottom socio-economic groups, with DI values ranging from 16 to 78 (see Fig. 1.3). In the year 2000/2001, only Brussels had a DI value below 20. In our study there are ten cities out of 20 with comparable data that have DI values higher than 40. Most South American and all three African cities belong to this group of cities, with Buenos Aires being most segregated of all cities included in the analysis. The only exception in South America is Mexico City, which has one of the lowest levels of segregation in this study. However, it has to be kept in mind that for Mexico City (and also for Buenos Aires) education was used instead of occupational status. And since income-heterogeneity is larger among educational groups compared to occupational groups, this might explain the relatively low-level of segregation in Mexico City.

\footnotetext{
${ }^{2}$ As mentioned before, we have made a selection of comparable case studies for analysis in this introductory chapter.
} 


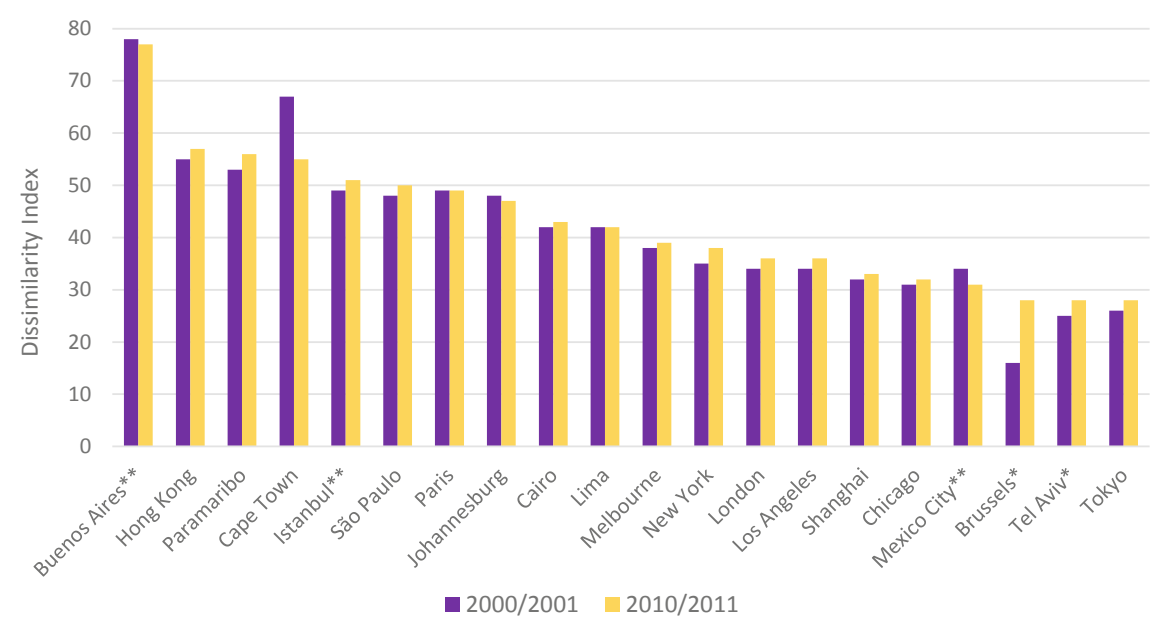

Fig. 1.3 Residential segregation between top and bottom socio-economic groups, 2000/2001 and 2010/2011. Source Individual chapters in this book, see Appendix 4 for more details). Notes *Top and bottom groups based on income; **Top and bottom groups based on educational attainment. Data for Paramaribo 2004 and 2012, Paris 1999 and 2015, Cairo 1996 and 2016, Lima 1993 and 2007, New York 2000 and 2013-2017, Mexico City 1990 and 2010, Tel Aviv 1995 and 2008

Figure 1.3 clearly shows that European cities do not necessarily have low levels of segregation as one might expect from their low levels of income inequality and the high levels of income redistribution in Europe. In fact, Paris is one of the most segregated cities in our study, with a level of segregation which is much higher than the Anglo-American cities, and comparable to Johannesburg in South Africa. The five cities with the lowest levels of segregation in this study are Tokyo, Tel Aviv, Brussels, Mexico City, and Chicago, which is a regionally very mixed group of cities. Interestingly, Hong Kong is one of the most segregated cities in this study, but this city is a-typical for Asia with its recent colonial past. All Anglo-American cities included into our study are modestly segregated.

While comparisons of levels of segregation between cities should be treated with some caution due to limitations in the comparability of data, the comparison of segregation levels over time within each city is more straightforward. Our results show that levels of segregation between the Top and Bottom socio-economic groups have increased (or remained stable in two cases) in most cities. However, these increases have been small for most cities, with the exception of Brussels. Segregation levels have dropped somewhat in four cities: Buenos Aires, Cape Town, Johannesburg, and Mexico City. Again, we should recall that the cases of Buenos Aires and Mexico City differ from the other cities because education is used as a measure of socio-economic status instead of occupation. Interestingly, in almost all cities in high-income countries levels of segregation have increased, while the situation in middle-income countries is a little more mixed. 
The low level of segregation in Tokyo is striking, especially because it is so much lower than in many European cities. In many European cities there is a strong overlap between ethnic and socio-economic segregation due to the on average low incomes of migrants compared to natives (Andersson and Kährik 2016). The share of international migrants in Tokyo is very small compared to other global cities, and at the same time Tokyo is characterised by a low level of income inequality, and strong public sector involvement in the economy, the housing market, and urban planning. Tokyo is also a very densely populated compact city, providing few opportunities for residential separation. In this context vertical segregation may be more important than the sorting of different socio-economic groups into different neighbourhoods (Hirayama 2017).

In addition to the case studies, Chap. 2 analyses income data from 194 cities in 14 OECD countries to provide an overview of residential segregation in a comparative perspective. Not surprisingly, segregation levels between the Top and Bottomincome groups were found to be much higher compared to segregation levels between Middle- and Bottom-income groups. The main contribution of this chapter to the book is the comparison of segregation levels of multiple cities within the same country. The results show that there is a lot of variation in levels of segregation between cities within some countries. With other words, studying only one case study city per country does not do justice to the variety of segregation levels within countries. Although generally speaking the analyses of OECD data show a relationship between levels of inequality and levels of income segregation, the results also suggest that local circumstances can greatly affect how levels of inequality are translated into the social geography of cities within a country. This needs to be taken into account when comparing single city case studies between countries as these case studies are not necessarily representative for the rest of the country.

\section{Conclusion 3. The higher the level of inequality, the higher the level of segregation.}

Previous studies have suggested that it takes time before a rise in income inequality leads to higher levels of socio-economic segregation. Therefore, it is important to take into account a time lag when studying the relationship (Marcińczak et al. 2015; Musterd et al. 2017; Wessel 2016; Tammaru et al. 2020). The time needed for transmitting changes in income inequality to changes in residential segregation varies from city to city, because of other factors shaping segregation. For example, in market dominated housing systems with little public interventions in housing, changes in income inequality may translate quickly (within ten years' time) into income-based residential sorting. However, in a housing system with a high share of social or public housing, and with strong policy interventions, the time lag between a change in income inequality and a change in residential segregation becomes longer, extending well beyond ten years (Wessel 2016). It is also important to note that the relationship tends to hold in both ways; an increase in income inequality is followed by an increase in residential segregation later in time, and a decrease in income inequality is followed by a decrease in residential segregation later in time (Tammaru et al. 2020). Our analysis of the relationship between income inequality (measured by Gini and lagged 10 years) and the level of socio-economic segregation has been summarised 

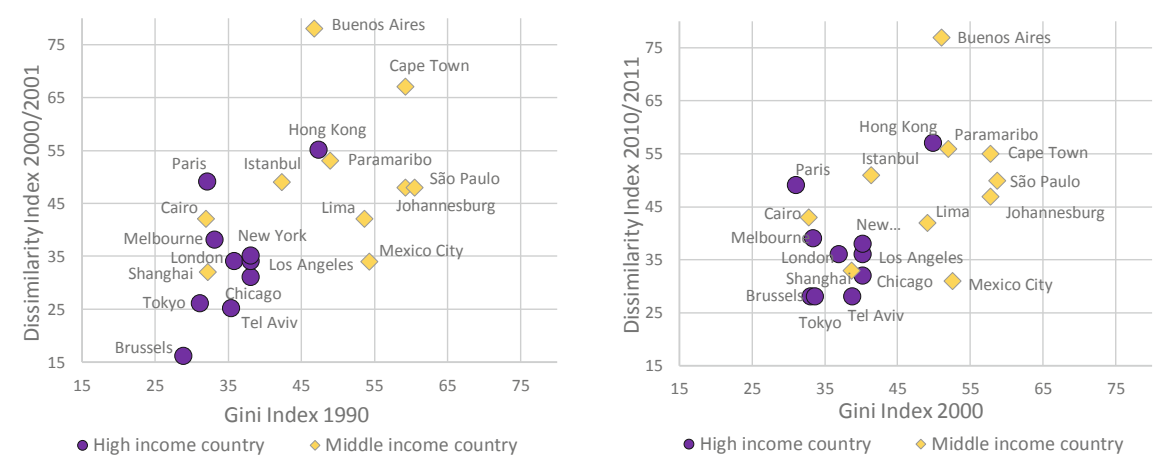

Fig. 1.4 Relationship between income inequality (lagged 10 years and) socio-economic residential segregation between Top and Bottom socio-economic groups. Source Individual chapters in this book and the World Bank

in Fig. 1.4. The graph on the left shows the relationship between the Gini Index measured in 1990 and the Dissimilarity Index as measured in 2000/2001, and the graph on the right shows the Gini Index measured in 2000 and the Dissimilarity Index measured in 2010/2011. The results show that there is a positive correlation between inequality and segregation and that this correlation is slightly weaker for the year 2010/2011 (0.529) compared to 2000/2001 (0.583). Off course there are outliers; Paris, for example, is much more segregated than expected based on the relatively low level of inequality in France. On the other hand, Mexico City is much less segregated than would be expected based on the inequality level in Mexico. These and other outliers show that the relationship between segregation and inequality is complex, and influenced by local circumstances. The data in Fig. 1.4 lead to further conclusions, which are discussed next.

\section{Conclusion 4. There are large differences between high-income and middle- income countries that converge with time.}

Figure 1.4 reveals that in the relationship between segregation and inequality there are separate clusters of high-income and middle-income countries. Generally speaking, middle-income countries combine high levels of inequality with high levels of segregation (particularly South American and South African cities), while high-income countries combine lower levels of inequality with lower levels of segregation. Of course, the pattern is not perfect, and again there are outliers. In 2010, the cities of Cairo and Shanghai, both from middle-income group of countries, show relatively low levels of inequality, and especially Shanghai also a low level of segregation. Mexico City on the other hand, shows a high level of inequality, combined with a very low level of segregation. And Paris, which is part of the high-income group of countries, combines a low level of inequality with a high level of segregation.

When comparing two graphs, it can be seen that the high-income country cluster moves upward because of a systematic increase in levels of inequality and segregation. While the changes in both income inequality and residential segregation are 
more diverse for the middle-income countries, this suggests convergence between the high-income and middle-income countries. The trend towards convergence between higher income and middle and low-income countries warrants some more attention. Further increases in both income inequality and residential segregation are not very likely in cities that are already highly unequal and highly segregated. The overall modernisation of societies and professionalisation of the labour force tends to reduce differences in incomes and residential sorting. However, the main reason for convergence relates to changes taking place in cities located in high-income countries. It is notable that increases in residential segregation in high-income countries tend to be larger than predicted by their levels of income inequality. Paris is the most outstanding case in this regard, where a very high level of residential segregation between the Top and Bottom socio-economic groups is combined with a low level of income inequality. In Paris, a possible explanation is related to migration, where lower income migrant households tend to cluster in modernist housing estates (Lelévrier and Melic 2018). In Paris, but also in other high-income cities, it may also be the case that an increased emphasis on market forces in the housing market increasingly sorts households with different financial means into different neighbourhoods, despite overall low levels of income inequality.

\section{Conclusion 5. The social geography of cities changes faster than levels of segregation measured city-wide.}

The data from this book shows an overall picture of increasing levels of socioeconomic segregation between 2000/2001 and 2010/2011, although segregation levels remained stable in some cities, and even dropped in others. Segregation was measured by using the Dissimilarity Index, and like many indices of segregation, it does not take into account the social geography of cities. In theory it is possible that over time the poor move to rich areas, and the rich to poor, while the overall measure of segregation remains stable.

Based on the case studies we can conclude that social geography of inequality is changing faster than measures of city-wide socio-economic segregation, as measured by the Dissimilarity Index. In many of the case study cities the Top socio-economic groups are concentrating in the centre and attractive coastal regions, and the Bottom socio-economic groups are concentrating on the edges of the urban region. In some cases, they are also concentrating in enclaves and gated communities outside the urban core. In all cases, the residential choices of the Top socio-economic groups are driving changes in the geography of segregation.

Beyond those general trends there are also many differences between the cities due to local circumstances, including historical, economic, and political factors, but also the physical geography of cities. There are some examples of cities in which the Top socio-economic groups concentrate in the central areas, and the Bottom socioeconomic groups in the periphery. In Shanghai, for example, the Top socio-economic groups concentrate into the centre as well as into certain suburbs. Also in Tel Aviv, London, Chicago, Buenos Aires, Melbourne, Paris, Mexico City, and New York the Top socio-economic groups are concentrating in the central area of the urban region. In all these cities they are more residentially concentrated than the Bottom 
socio-economic groups. We also observed in all these cities that the Bottom socioeconomic groups increasingly live in the urban periphery. For example, in Berlin it was observed that child poverty is increasingly moving to the urban periphery, which is likely to increase inequality due to a lack of opportunity for these children as they grow up.

In Chicago, the city seems to be polarising geographically with an increasing residential division between the Top and Bottom socio-economic groups. In many other cities there is an increase of socio-economically mixed areas due to gentrification. This is the case in, for example, New York, Paris, and Mexico City. Los Angeles has a more geographically dispersed pattern of residential inequality than the cities mentioned above. This is due to the polycentric nature of the urban region, with concentrations of Top socio-economic groups in various parts of the city, gentrification in adjacent areas of rich enclaves, and a rise in the number of gated communities. Cities like São Paulo, Istanbul, Lima, and Hong Kong are also characterised by a concentration of the Top socio-economic groups in the central area of the city. At the same time, also gated communities for the high-income groups can be found in these urban regions.

Some cities, like Johannesburg, Cape Town, Paramaribo, and Cairo, show an opposite geography of residential inequality. In these cities the Bottom socio-economic groups are concentrating into the city centre and the periphery, and the Top socioeconomic groups are concentrating in suburbs and gated communities. In Brussels the central area of the city is quite deprived and the outskirts are more prosperous; the Top socio-economic groups mainly concentrate in the peripheral areas (but also in some pockets in the central area), and the Bottom socio-economic groups concentrate in and around the centre in densely populated neighbourhoods. The cities of Tokyo, Mumbai, and Bogotá all show very distinct patterns of segregation. In Tokyo, the Top socio-economic groups live in the elevated areas in the West, and in the harbour area, and the Bottom socio-economic groups live in the lowlands in the East. In Mumbai there is a clear North-South division, with the Top socio-economic groups living in the South, and the Bottom socio-economic groups living in the North. And in Bogotá the Top socio-economic groups live in the North, and the Bottom socio-economic groups live in the South. For Jakarta, the spatial units were too large for an in-depth analysis of the geographical patterns of inequality.

Many cases reveal that residential areas in the city centres are getting more socioeconomically mixed due to gentrification and expansion of the urban core. This is the case in, for example, Hong Kong, Mumbai, London, Berlin, and Paris. The fact that urban cores in these cities become more mixed might be a temporary phenomenon as in the course of the process of gentrification these areas become unaffordable for Bottom socio-economic groups, and become over-represented by more and more affluent households. Although this book predominantly studies socioeconomic segregation, many case studies also mention the link between ethnic segregation and socio-economic segregation. The clear South-North division in Mumbai is strongly related to ethnic and religious segregation in the city. Segregation in Tel Aviv is also related to both ethnicity and religion. In London, Chicago, New York, 
and Paris, socio-economic segregation is also strongly related to patterns of racial and ethnic segregation.

\subsection{A Global Segregation Thesis}

The central research question of this book was whether there is any evidence for a Global Segregation Thesis, or whether cities in different parts of the world show very distinctive patterns of socio-economic segregation? Taken together, the five main conclusions of this book provide support for what we call the Global Segregation Thesis, which is characterised by a global trend of rising levels of segregation, combined with a changing social geography of cities. Rising levels of segregation are caused by rising levels of income inequality, and although the link between the two is complex, it seems almost universal and globally applicable. At the same time the social geography of cities is changing, where high-income households increasingly live in city centres and other attractive areas, while lower income households move to the fringes of the city. This changing social geography is related to the professionalisation of the urban workforce, which leads to more higher income households, which have developed a preference for living in central parts of large cities. Levels of segregation have not gone up as much as could be expected based on rising levels of inequality, and this is possibly due to gentrification and the temporally socioeconomic mixing of central city neighbourhoods. Over time, processes of gentrification will lead to further increases in levels of segregation. The combination of rising levels of inequality and professionalisation of the workforce is expected to lead to a further increase in segregation and more uneven landscapes of opportunity.

For most cities in this book, the most recent census data used was from 2010 or 2011, and data from the next (2020 or 2021) census will not be available for another 5 years. This means that the 2010/2011 census only started to capture the effects of the 2008 Global Financial Crisis. At the time of writing this introduction, the world is facing a new economic crisis related to the COVID-19 pandemic. Although it is impossible to know how long and deep this crisis will be, there are signs that the weakest in society will be hit the hardest. This is likely to lead to rising levels of inequality, and ultimately more segregation in cities. At the same time there are discussions on the future of cities and on the residential preferences of higher income households. These households might decide to leave their relatively small dwellings in densely populated areas and live in more spacious dwellings in suburban environments. Such a change might have dramatic effects on the social geography of cities and spaces of opportunity. Densely populated areas might increasingly become the domain low-income groups, while higher income groups once again suburbanise as they did decades ago. In the short run it can be expected that levels of socio-economic segregation continue to rise and that the social geography of cities continues to show a pattern of rich centres, with poor suburbs. In the long run cities are in constant flux, and the future of cities depends on many factors yet still unknown. 
Future research on inequality and socio-economic segregation should focus on better understanding local variation in the relationships between the two. And most importantly, how different urban policies-area-based, people-based, and connectivity-based-can make a difference? It is also important to improve our understanding on how residential inequalities are produced and reproduced over different life domains (home, family, education, work) and across generations. Understanding the vicious cycle of segregation and inequality can lead to more effective policies aimed at improving access to opportunity. The professionalisation of the urban workforce and increasing educational levels leads to a higher share of highincome earners in cities, which initially leads to more social mix in many urban neighbourhoods. But in the longer run these trends might lead to higher levels of segregation as cities become more and more unaffordable for many people. It is therefore crucial to take a multi-scale perspective on cities (Petrović et al. 2018), studying large urban regions instead of cities. Finally, as global cities are increasingly multi-ethnic, the overlap between income inequality and ethnicity and race in many cities needs further attention. The most severe and persistent inequalities appear where different variables intersect, and these intersections require most attention.

\section{Appendix 1: Guidelines for Authors, Data, and Methods}

Each chapter should contain two parts: a compulsory part including an analysis of changes in the occupational structure, income inequality, and residential segregation; and a free part, which discusses the local context and other important factors related to segregation in the specific country or city. To define urban regions, all authors should use functional urban areas as defined by the OECD. Socio-economic groups are preferably distinguished based on occupational status, and classified into Top, Middle, and Bottom (or High, Middle, and Low for educational or income levels). The main measure of segregation to be used is the Dissimilarity Index. Chapters should preferably provide the city-level Gini index, and otherwise the national-level Gini index. To analyse the geography of segregation authors were asked to construct some standard maps using guidelines provided by the editors. For calculations of the Dissimilarity Index and the construction of maps, authors were asked to use small spatial units, preferably census tracts of around 5000 inhabitants. And authors were asked to analyse data from at least the year 2000/2011 and 2010/2011, but a longer period of analysis was welcome if data allowed.

A functional urban area consists of a city and its commuting zone (OECD 2013).

In this book occupational categories are used as a proxy for socio-economic status. Occupational categories are derived from the International Standard Classification of Occupations (ISCO) (ILO 2012) and they are directly comparable and available in all countries conducting censuses. People with different occupations do not only perform different tasks, but occupational attainment is also closely related to personal work income. A typical example of this classification, which applies to many cities, 
is TOP: managers + professionals; MIDDLE: everything in between; BOTTOM: elementary occupations + plant and machine operators and assemblers.

The Gini index is the most commonly used measurement of inequality. It is the ratio of income distribution within a country or city, where 0 represents perfect equality with no income differences between individuals and 100 represents perfect inequality with one person earning all income.

Dissimilarity Index $(D I)$ is used as the main measure of residential segregation between socio-economic groups, reflecting their relative distributions across neighbourhoods within the urban area. Value of DI varies between 0 and 100, which indicates the proportion of a group that would need to move in order to create a uniform distribution of population. 0 means that both groups are distributed in the same proportions across all neighbourhoods and 100 means that the members of two groups are located in different neighbourhoods - this is a total segregation. The Dissimilarity Index is calculated as follows:

$$
D I=\frac{1}{2} \sum_{i=1}^{N}\left|\frac{a_{i}}{A}-\frac{b_{i}}{B}\right|
$$

where $a_{i}$ is the population of group A in the ith area, e.g., census tract; A is the total population in group $\mathrm{A}$ in the large geographic entity for which the index of dissimilarity is being calculated; $b_{i}$ is the population of group B in the ith area; B is the total population in group B in the large geographic entity for which the index of dissimilarity is being calculated. The DI is the main measure of segregation in this book, but additional measures were used by some chapters:

Interaction or Exposure Index $(B)$ measures the degree of potential contact or the possibility of interaction between the members of two groups within the neighbourhoods. The value of this index varies between 0 and 100 and it is the highest when the two groups have equal numbers and are spread evenly among neighbourhoods.

Entropy index (EI) measures the spatial distribution of multiple groups simultaneously. Value of EI varies between 0 and 100. It is equal to 0 when the composition of all neighbourhoods is the same, and it is equal to 100 , when all neighbourhoods inhabit only one group.

In addition to the Dissimilarity Index between occupational categories, authors were asked to provide maps. The main reason is that similar measures of segregation can have completely different underlying geographies. Authors were asked to provide the following maps:

- Location quotient (LQ) maps for the Top and Bottom occupational status groups. The LQ is a way of quantifying how concentrated a particular group is in each neighbourhood compared to the average for the entire urban area. LQ greater than 1 indicates that the neighbourhood has a higher than average concentration of particular group.

- Classification of neighbourhoods by socio-economic composition based on the typology provided by Marcińczak et al. (2015). Some chapters adopted a slightly different approach and explained the modifications in their chapters. 
- Location of the Top socio-economic status groups, which shows how many neighbourhoods house $20 \%$ of the Top group. The fewer neighbourhoods are needed to get to $20 \%$, the more concentrated the Top group is. In theory, $20 \%$ of the Top group can live in one neighbourhood, which means that the group is very spatially concentrated. Even when the segregation index remains similar over time, the spatial location of the Top group could have changed.

\section{Appendix 2: Summary Table of Data Used for Each Case Study City}

\begin{tabular}{l|l|l|l|l|l}
\hline City & $\begin{array}{l}\text { Population } \\
\text { of an } \\
\text { urban } \\
\text { region, in } \\
\text { mln }\end{array}$ & $\begin{array}{l}\text { Average } \\
\text { size of } \\
\text { the } \\
\text { spatial } \\
\text { unit used } \\
\text { in the } \\
\text { analysis }\end{array}$ & Year of analysis & $\begin{array}{l}\text { Main variable } \\
\text { used }\end{array}$ & $\begin{array}{l}\text { World Bank } \\
\text { classification } \\
\text { by income }\end{array}$ \\
\hline Berlin & 6.0 & 8,400 & $2007-2012-2016$ & $\begin{array}{l}\text { Unemployment, } \\
\text { child poverty, } \\
\text { migration } \\
\text { background }\end{array}$ & High income \\
\hline Bogotá & 6.8 & $\begin{array}{l}\text { Not } \\
\text { provided }\end{array}$ & 2005 & $\begin{array}{l}\text { Educational } \\
\text { groups }\end{array}$ & $\begin{array}{l}\text { Upper } \\
\text { middle } \\
\text { income }\end{array}$ \\
\hline Brussels & 2.5 & 2,834 & $2001-2011-2016$ & Income & High income \\
\hline Buenos Aires & 13.0 & 800 & $1991-2001-2010$ & $\begin{array}{l}\text { Educational } \\
\text { groups }\end{array}$ & $\begin{array}{l}\text { Upper } \\
\text { middle } \\
\text { income }\end{array}$ \\
\hline Cairo & 20.4 & 8,250 & $1986-1996-2006$ & $\begin{array}{l}\text { Occupational } \\
\text { groups }\end{array}$ & $\begin{array}{l}\text { Lower } \\
\text { middle } \\
\text { income }\end{array}$ \\
\hline Jakarta & 31.6 & 750,000 & $2011-2018$ & $\begin{array}{l}\text { Occupational } \\
\text { groups }\end{array}$ & $\begin{array}{l}\text { Upper } \\
\text { middle } \\
\text { income }\end{array}$ \\
\hline Istanbul & 15.0 & 15,600 & $2000-2010-2017$ & $\begin{array}{l}\text { Educational } \\
\text { groups }\end{array}$ & $\begin{array}{l}\text { Upper } \\
\text { middle } \\
\text { income }\end{array}$ \\
\hline Chicago & 9.5 & 4,000 & $1990-2000-2010-2015$ & $\begin{array}{l}\text { Occupational } \\
\text { groups }\end{array}$ & High income \\
\hline groups & 4.6 & 10,140 & $2001-2011$ & $\begin{array}{l}\text { Oower } \\
\text { groups } \\
\text { income }\end{array}$ \\
\hline & 7.5 & 2,162 & $2001-2011-2016$ & $\begin{array}{l}\text { Occupational } \\
\text { Kong }\end{array}$ & 4 High income \\
\hline
\end{tabular}


(continued)

\begin{tabular}{|c|c|c|c|c|c|}
\hline City & $\begin{array}{l}\text { Population } \\
\text { of an } \\
\text { urban } \\
\text { region, in } \\
\text { mln }\end{array}$ & $\begin{array}{l}\text { Average } \\
\text { size of } \\
\text { the } \\
\text { spatial } \\
\text { unit used } \\
\text { in the } \\
\text { analysis }\end{array}$ & Year of analysis & $\begin{array}{l}\text { Main variable } \\
\text { used }\end{array}$ & $\begin{array}{l}\text { World Bank } \\
\text { classification } \\
\text { by income }\end{array}$ \\
\hline Johannesburg & 15.0 & 2,158 & 2001-2011 & $\begin{array}{l}\text { Occupational } \\
\text { groups }\end{array}$ & $\begin{array}{l}\text { Upper } \\
\text { middle } \\
\text { income }\end{array}$ \\
\hline Lima & 9.5 & 5,443 & 1993-2007 & $\begin{array}{l}\text { Occupational } \\
\text { groups }\end{array}$ & $\begin{array}{l}\text { Upper } \\
\text { middle } \\
\text { income }\end{array}$ \\
\hline London & 9.0 & 1,400 & 2001-2011 & $\begin{array}{l}\text { Occupational } \\
\text { groups }\end{array}$ & High income \\
\hline Los Angeles & 18.8 & 4,000 & 1980-1990-2000-2010 & $\begin{array}{l}\text { Occupational } \\
\text { groups }\end{array}$ & High income \\
\hline Melbourne & 4.5 & 7,933 & 2001-2006-2011-2016 & $\begin{array}{l}\text { Occupational } \\
\text { groups }\end{array}$ & High income \\
\hline Mexico City & 22.0 & 3,485 & 1990-2000-2010 & $\begin{array}{l}\text { Educational } \\
\text { groups }\end{array}$ & $\begin{array}{l}\text { Upper } \\
\text { middle } \\
\text { income }\end{array}$ \\
\hline Mumbai & 12.4 & 140,909 & 1991-2001-2011-2018 & $\begin{array}{l}\text { Class, religion, } \\
\text { castes and tribes }\end{array}$ & $\begin{array}{l}\text { Lower } \\
\text { middle } \\
\text { income }\end{array}$ \\
\hline New York & 17.0 & 4,000 & 2000-2008/2012-2013/2017 & $\begin{array}{l}\text { Occupational } \\
\text { groups }\end{array}$ & High income \\
\hline Paramaribo & 0.4 & 3,611 & 2004-2012 & $\begin{array}{l}\text { Occupational } \\
\text { groups }\end{array}$ & $\begin{array}{l}\text { Upper } \\
\text { middle } \\
\text { income }\end{array}$ \\
\hline Paris & 12.5 & 2,500 & 1990-1999-2015 & $\begin{array}{l}\text { Occupational } \\
\text { groups }\end{array}$ & High income \\
\hline São Paulo & 20.0 & 32,000 & $2000-2010$ & $\begin{array}{l}\text { Occupational } \\
\text { groups }\end{array}$ & $\begin{array}{l}\text { Upper } \\
\text { middle } \\
\text { income }\end{array}$ \\
\hline Shanghai & 23.0 & 3,000 & $2000-2010$ & $\begin{array}{l}\text { Occupational } \\
\text { groups }\end{array}$ & $\begin{array}{l}\text { Upper } \\
\text { middle } \\
\text { income }\end{array}$ \\
\hline Tel Aviv & 3.2 & 1,484 & $1995-2008$ & Income & High income \\
\hline Tokyo & 35.7 & 3,000 & 2000-2005-2010-2015 & $\begin{array}{l}\text { Occupational } \\
\text { groups }\end{array}$ & High income \\
\hline
\end{tabular}




\section{Appendix 3: Occupational Structure of Comparable Case Study Cities (Source Individual Chapters in This Book)}

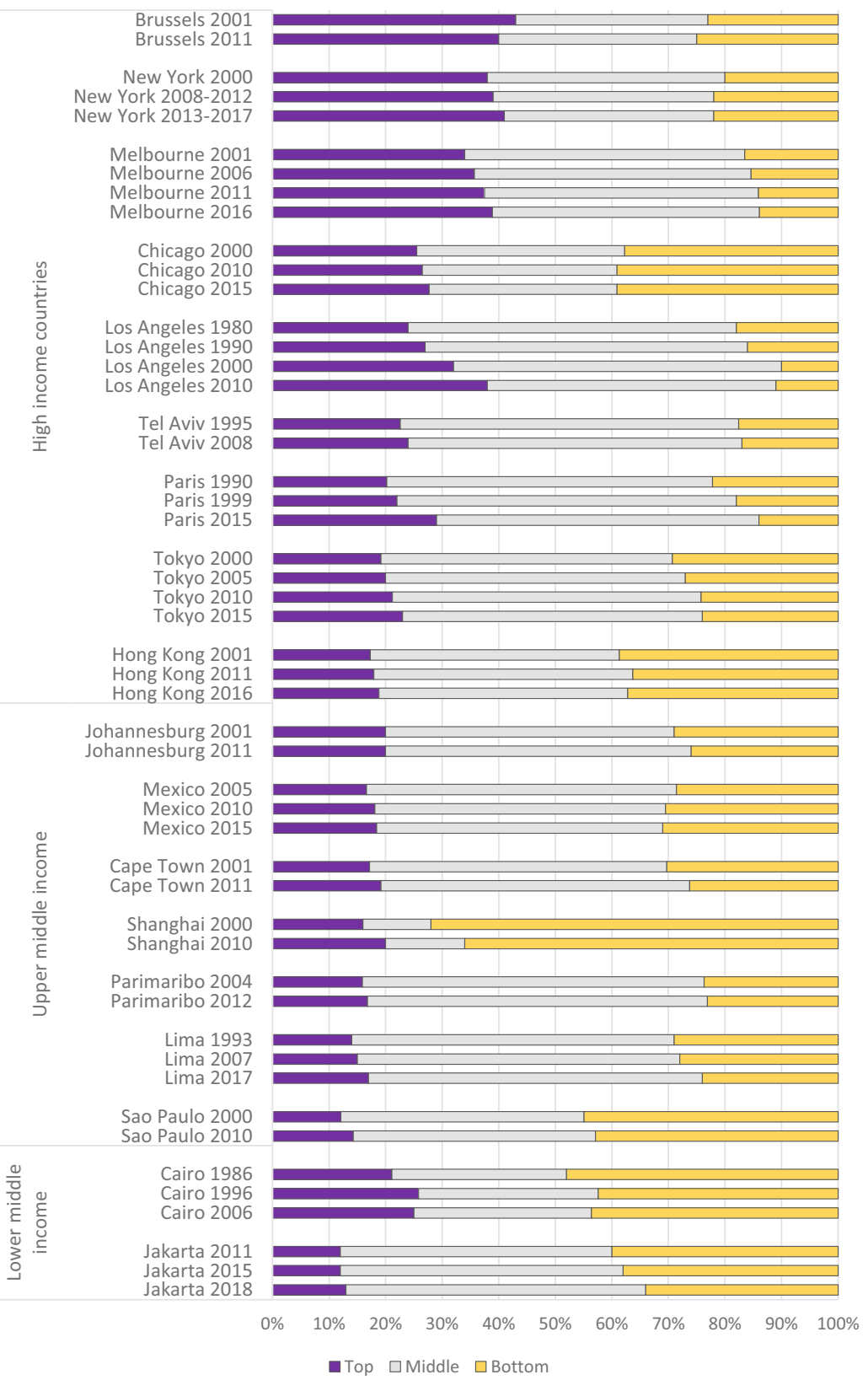




\section{Appendix 4: Dissimilarity Indices Between Top and Bottom Socio-economic Status Groups, in All Years Provided by the Authors (Source Individual Chapters in This Book)}

\begin{tabular}{l|l|l|l|l|l|l}
\hline City name & 1990 & 2000 & 2005 & 2010 & 2015 & Average \\
\hline Buenos Aires & 79 & 78 & & 77 & & 78.0 \\
\hline Cape town & & 67 & & 55 & & 61.0 \\
\hline Paramaribo & & 53 & & 56 & & 54.5 \\
\hline Hong Kong & & 55 & & 57 & 50 & 54.0 \\
\hline São Paulo & & 48 & & 50 & & 49.0 \\
\hline Paris & 47 & 49 & & & 49 & 48.3 \\
\hline Istanbul & & 49 & & 51 & 44 & 48.0 \\
\hline Johannesburg & & 48 & & 47 & & 47.5 \\
\hline Cairo & 43 & 42 & & & 43 & 42.7 \\
\hline Lima & 42 & & 42 & & & 42.0 \\
\hline Melbourne & & 38 & 39 & 39 & 38 & 38.5 \\
\hline Mexico City & 34 & 45 & & 31 & & 36.7 \\
\hline New York & & 35 & & & 38 & 36.5 \\
\hline London & & 34 & & 36 & & 35.0 \\
\hline Los Angeles & 31 & 34 & & 36 & & 33.7 \\
\hline Shanghai & & 32 & & 33 & & 32.5 \\
\hline Chicago & & 31 & & 32 & 33 & 32.0 \\
\hline Tokyo & & 26 & 27 & 28 & 28 & 27.3 \\
\hline Tel Aviv & & 25 & & 28 & & 26.5 \\
\hline Mumbai & 24 & 24 & & 23 & & 23.7 \\
\hline Brussels & & 16 & & 28 & & 22.0 \\
\hline Jakarta & & & & 13 & 9 & 11.0 \\
\hline Note The year provir & & & & & & \\
\hline
\end{tabular}

Note The years provided in the table and chapters may vary slightly, e.g. Cairo chapter provides data for 2016, not 2015

\section{References}

Alvaredo F, Chancel L, Piketty T, Saez E, Zucman G (2018) World inequality report 2018. Cambridge Massachusetts: The Belknap Press of Harvard University Press. https://wir2018.wid. world/. Accessed 22 June 2020

Andersson R, Kährik A (2016) Widening gaps: segregation dynamics during two decades of economic and institutional change in Stockholm. In: Tammaru T, Marcińczak S, van Ham M, Musterd S (eds) Socio-economic segregation in European capital cities: east meets west. Routledge, London and New York, pp 110-131 
Butler T, Hamnett C, Ramsden M (2008) Inward and upward: marking out social class change in London, 1981-2001. Urban Stud 45(2):67-88

Corak M (2013) Income inequality, equality of opportunity, and intergenerational mobility. J Econ Perspect 27(3):79-102

Davidson M, Wyly E (2015) Same, but different: within London's 'static' class structure and the missing antagonism. City 19(2-3):247-257

Commission European, Habitat UN (2016) The state of European cities 2016: cities leading the way to a better future. European commission, directorate-general for regional and urban policy, Brussels

Fujita K, Maloutas T (eds) (2016) Residential segregation in comparative perspective: making sense of contextual diversity. Routledge, London

Hamnett C (1994) Social polarisation in global cities: theory and evidence. Urban Stud 31(3):401424

Hamnett C (2009) The new mikado? tom slater, gentrification and displacement. City 13(4):476-482

Harvey D (1985) The urbanisation of capital. Johns Hopkins University Press, Baltimore

Hirayama Y (2017) Selling the Tokyo sky: urban regeneration and luxury housing. In Cities and the super-rich, pp 189-208, Palgrave Macmillan, New York

Hulchansky D (2010) The three cities in Toronto: Income polarization among Toronto's neighbourhoods, 1970-2005. University of Toronto, Toronto

International Labour Organization (2012) International standard classification of occupations: structure, group definitions and correspondence tables. https://www.ilo.org/wcmsp5/groups/pub lic/—dgreports/—dcomm/_-publ/documents/publication/wcms_172572.pdf. Accessed 22 June 2020

Kazepov Y (ed) (2005) Cities of Europe, changing contexts, local arrangement and the challenge to urban cohesion. Wiley-Blackwell, London

Kornai J (1992) The socialist system: the political economy of communism. Princeton University Press, Princeton, NJ

Krueger A (2012) The rise and consequences of inequality in the United States, presentation at the center for American progress in Washington, DC January 12, 2012. https://pages.wustl.edu/files/ pages/imce/fazz/ad_10_1_krueger.pdf. Accessed 1 Jan 2018

Lelévrier C, Melic T (2018) Impoverishment and social fragmentation in housing estates of the Paris region, France. In Housing estates in Europe, pp 313-338, Springer, Cham

Manley D, Johnston R (2014) London: a dividing city, 2001-11? City 18(6):633-643

Marcińczak S, Tammaru T, Novák J, Gentile M, Kovács Z, Temelová J, Valatka V, Kährik A, Szabó B (2015) Patterns of socioeconomic segregation in the capital cities of fast-track reforming postsocialist countries. Ann Assoc Am Geogr 105(1):183-202

Massey DS, Denton NA (1993) American apartheid: Segregation and the making of the underclass. Harvard University Press, Cambridge, Massachusetts, London

Musterd S, Marcińczak S, van Ham M, Tammaru T (2017) Socio-economic segregation in European capital cities. Increasing separation between poor and rich. Urban Geogr 38(7):1062-1083

Musterd S, Ostendorf W (1998) Urban segregation and the welfare state: inequality and exclusion in western cities. Routledge, London

OECD (2013) Definition of functional Urban areas (FUA) for the OECD metropolitan database. http://www.oecd.org/regional/. Accessed 10 Sep 2018

Petrović A, van Ham M, Manley D (2018) Multiscale measures of population: Within-and betweencity variation in exposure to the sociospatial context. Ann Am Assoc Geogr 108(4):1057-1074

Piketty T (2014) Capital in the twenty-first century. The Belknap Press of Harvard University Press, Cambridge Massachusetts

Sassen S (1991) The global city: New York, London, Tokyo. Princeton University Press, Princeton Sýkora L (2009) New socio-spatial formations: places of residential segregation and separation in Czechia. Tijdschrift voor Economische en Sociale Geografie 100:417-435 
Tammaru T, Marcińczak S, Aunap R, van Ham M, Janssen H (2020) Understanding the relationship between income inequality and residential segregation between socioeconomic groups. Reg Stud 54(4):450-461

Tammaru T, Marcińczak S, van Ham M, Musterd S (2016) Socio-economic segregation in European capital cities: east meets west. Routledge, London and New York

van Ham M, Uesugi M, Tammaru T, Manley D, Janssen H (forthcoming) Changing occupational structures and residential segregation in New York, London and Tokyo. Nature human behaviour

van Ham M, Tammaru T, Janssen H (2018) A multilevel model of vicious circles of socioeconomic segregation. In Divided cities: understanding intra-urban inequalities, pp 135-153, OECD Publishing, Paris

Wessel T (2016) Economic segregation in Oslo: polarisation as a contingent outcome. In: Tammaru T, Marcińczak S, van Ham M, Musterd S (eds) Socio-economic segregation in European capital cities: east meets west. Routledge, London and New York, pp 132-155

World Bank (2020) World bank country and lending groups. https://datahelpdesk.worldbank.org/ knowledgebase/articles/906519. Accessed 10 Feb 2020

Open Access This chapter is licensed under the terms of the Creative Commons Attribution 4.0 International License (http://creativecommons.org/licenses/by/4.0/), which permits use, sharing, adaptation, distribution and reproduction in any medium or format, as long as you give appropriate credit to the original author(s) and the source, provide a link to the Creative Commons license and indicate if changes were made.

The images or other third party material in this chapter are included in the chapter's Creative Commons license, unless indicated otherwise in a credit line to the material. If material is not included in the chapter's Creative Commons license and your intended use is not permitted by statutory regulation or exceeds the permitted use, you will need to obtain permission directly from the copyright holder.

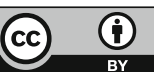

